San Antonio Review • San Antonio Review (Volume V | Summer 2021)

\title{
Paulette Jiles and the \\ 'Aura' of the News
}

John Willingham

Published on: Feb 03, 2021

DOI: $10.21428 / 9 b 43 c d 98 . b e 461075$

License: Creative Commons Attribution 4.0 International License (CC-BY 4.0). 


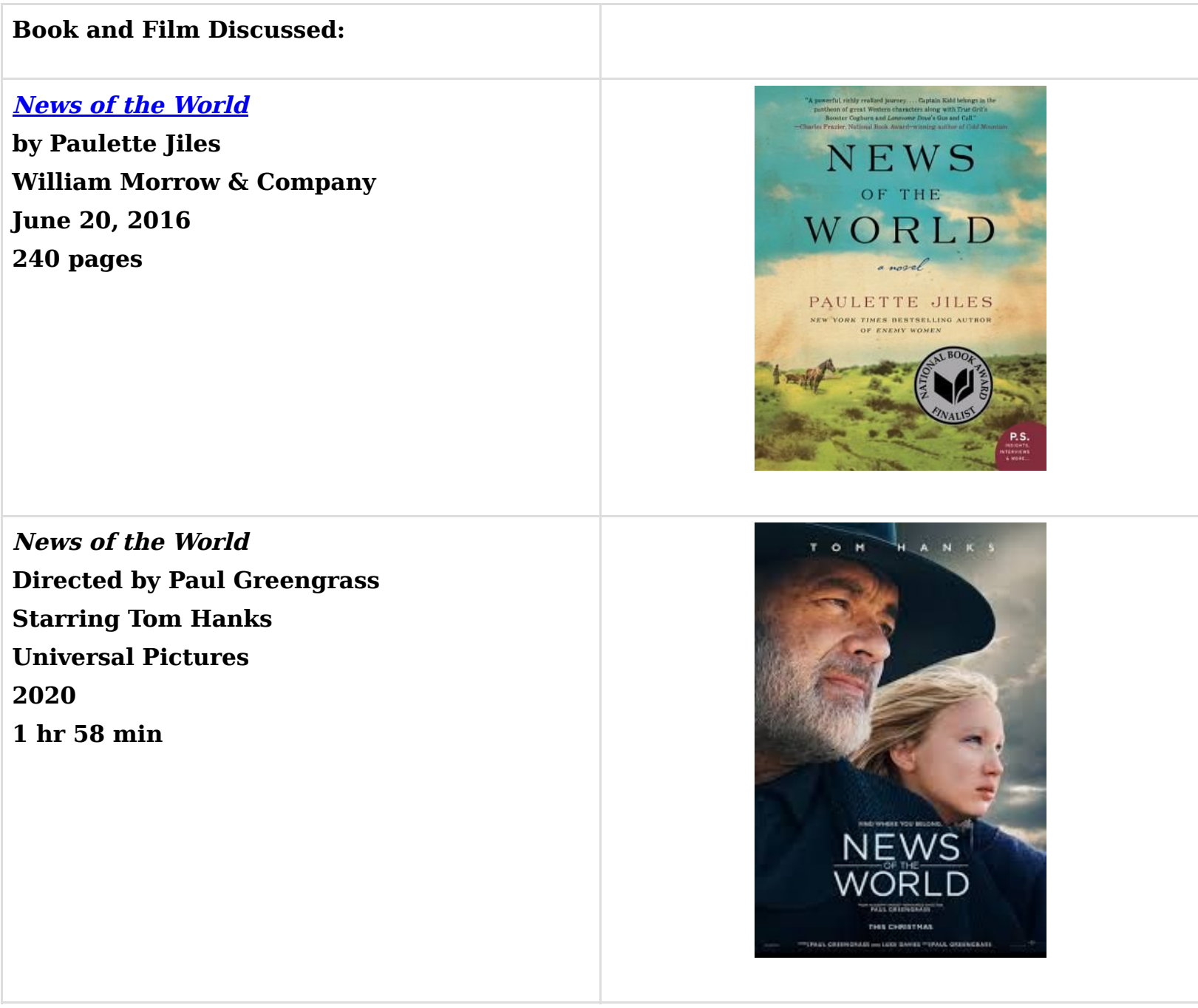

\section{I.}

Long before he was a reader of the news, and decades before he owned a press that printed it, Jefferson Kyle Kidd, a natural runner, carried messages for the army at the age of sixteen, his strong legs and lungs having been seasoned in the north Georgia mountains. He jogged through South Alabama and South Georgia, down to Pensacola and back to Mobile, dodging British patrols and Red Stick Creek warriors. For two years he carried maps and reports for General Jackson, maps that only showed directions but couldn't feel the ground. It was the running, the fast traveling that he loved. He missed the Battle of New Orleans; it would have been anticlimactic.

"He always recalled those two years with a kind of wonder," writes Paulette Jiles, of the protagonist in her novel News of the World. 
"As when one is granted the life and the task for which one was meant. No matter how odd, no matter how out of the ordinary. When it came to an end he was not surprised. It was too good, too perfect to last."

Wounded at the Battle of Horseshoe Bend, though not so severely as another young man on the field that day, Sam Houston, Kidd returned to Macon when the fighting was over and learned the printing trade. In the 1830s he went to Texas, during the Republic, and settled in San Antonio. "He loved print, felt something right about sending out information into the world. Independent of its content." It was the work itself, the process, that he relished.

Another decade passed, and another war pulled him in - this time at the age of 48 . The Army wanted him to print orders for General Taylor, who was leading American troops in the Mexican War. Using only a small hand press, Kidd not only printed what the general needed but found himself in charge of couriers, sometimes including Texas Rangers and their like, born to ride their fast, rudely tamed horses. Young men, bold, even cruel, they still needed reassurance from a blooded soldier. "They wanted some wisdom, some advice. You can get hit and not know it, he said. So could the man next to you. Take care of one another," an officer told him.

Sending out information into the world? It was wise counsel he gave directly to the Rangers, earned wisdom. The printing work he did, not the wisdom, brought him to the brevet rank of Captain. And a Captain he remains in the story.

"Afterward, late, when he was alone and the fire of mesquite wood was dying, it came to him that he should take on the task of dispensing these interesting, nay, vital facts gleaned from the intelligence reports and the general press. For instance, the struggles going on at the top levels of the Mexican Army. If people had true knowledge of the world perhaps they would not take up arms and so perhaps he could be an aggregator of information from distant places and then the world would be a more peaceful place. He had been perfectly serious. That illusion had lasted from age forty-nine to age sixty-five. And then he had come to think that what people needed, at bottom, was not only information but tales of the remote, the mysterious, dressed up as hard information. And he, like a runner, immobile in his smeared printing apron bringing it to them. Then the listeners would for a small space of time drift away into a healing place like curative waters." 
And then he had come to think ... after the Civil War, indescribable in its horror, that he could offer the world some tales, dressed up for their consumption, and somehow curative. And therein Jiles hints that the authentic stories of the world have the potential to be "curative" only if they make their remoteness immediate, and their mystery alive. In them are moving parts far more complex than those of the machines that seek to render them for consumption. These are the stories that Jiles creates, almost in the manner of ancient oral traditions. If there is healing, it is within and of the story, not at a destination.

What Jiles strives for is similar to what the late philosopher Walter Benjamin referred to as the "aura" of the work of art: "the here and now of the work of art - its unique

existence in a particular place." 1 (Jiles first read Benjamin in college; even recently she has mentioned his writing on her website.)

The here and now of the story is not static; rather it arises from a "strange weave of place and time," based above all on the interplay of people in motion and adapting, or not, to their world. Here and now only appear to be the present, for the "present" is organic and dynamic, a compound of what we think of as past present and place, all in motion, always carrying the cusp of the future. This view of art - and of reality resembles that of William Faulkner and of many philosophers, with one important difference: Faulkner was keen to present the process as it was experienced internally by his characters, using stream of consciousness, most notably in The Sound and the Fury. Jiles chooses the way of the traditional storyteller, featuring people "on a trip" with "something to tell about," and that "something" is embedded in the trip itself. Her goal is to place us with them, and them with us, all moving together. For in her created world, that is as close as it gets to authentic existence.

\section{II.}

As a young woman Jiles wrote poems, books of poems, some honored with prizes. The poems were mostly narrative, and in them were many vehicles, especially trains, connected front back and middle but moving on from station to station. She wrote many of the poems while living with the Ojibway in the Arctic Circle, a place without trains.

"Where I was for about ten years was seven hundred miles straight north of Minneapolis," she wrote in Southwest Review (1993), in a story, real or seemingly so, called "The Spontaneously Created People," the name the Ojibway gave to themselves. 
"They've never been pushed anywhere or removed or herded off-world. They are where they have been for eight thousand years, and so the stories are quite sure as to where the nations are, and spots of origins where things are spontaneously created and places where we go when our spontaneity runs out."를

But the poems, written years earlier, are testimony to Jiles's personal journey and not to an isolated people's enviable and natural ties to the authentic stories of their existence. Of her books Waterloo Express and Celestial Navigation, Canadian critic Francis Mansbridge, writing in 1991, tells us something of Jiles's interior life: “In Waterloo Express (1973), much of the anguish comes from her relationship with men; in Celestial Navigation (1984), beginning with the poem 'Time to Myself,' especially, men have moved toward the periphery of her poetic world - often they seem more a part of the civilized centre of her past." $\underline{3}$

Another Canadian critic, M. Travis Lane, while recognizing the personal elements in Jiles's poetry, was prescient in her description of Jiles's development as a writer dedicated to ancient and enduring patterns. $\underline{4}$

“Jiles's Waterloo Express is set in the universe of perpetual flight which, from Heraclitus through Pater to Einstein, has increasingly presented itself as reality to the philosophic temperament, if not, as yet, to the common man. The transport images in Jiles's poetry - train, boat, truck, car, horse - are not merely the means of travel but the traveling world. Movement, present or imminent, is mentioned in every poem: things are in flight, or about to 'pop,' about to discover the 'endless possibilities beyond,' to climb or to swim, to be thrown away, to be carried off." [Emphasis added.]

Poetry "seemed to be the only area to which I could move," Jiles said in an interview with Southwest Review in 1993, her fiftieth year, "because the only thing in the sixties that seemed to be available was the novel of bourgeois, urban, domestic relationships, and I did not come from that kind of urban, educated, upper middle class, white background, and I couldn't even fake it, although god knows I tried. . . . I'm from the Ozarks. I am from an extended family, a very strong, very marked culture. In university this was unacceptable. People from southern Missouri were rednecks, hillbillies, they were hicks, they were people of no account, and even to mention that I came from there would usually bring stares of derision. . . . So it was either poetry in which I could express my interior life, or the novel. It was one or the other; there was nothing in between." $\underline{5}$ 
Growing restless and still yearning to write novels, Jiles found herself back in Missouri in the late eighties. As a lifelong lover of horses, she went to a horse fair at the Jacks Fork River in the Missouri Ozarks. And there she met Jim Johnson. A decorated Army veteran of Vietnam, retired lieutenant colonel turned rancher, Jim Johnson was a man who, Jiles said, "got in the way of big events." Quickly realizing that she was "in love in bad way," Jiles also began "to get fed up with my life just being poems." She was ready to travel the country - with Jim Johnson. Jiles had an idea. She had about a battalion of cousins scattered across the southeastern United States. She sold her agent on a book project: she would find the cousins, listen to their stories, and write them up. She and Jim, in an old Ford pickup pulling a tiny greenhouse trailer that had a pull-down table and an undersized bed, took off together not long after the horse fair at Jakes Fork River. He was leaving his wife and ranch behind, feeling, as Jiles did, that it was time to get moving. He had gotten in the way of another big event.

In her semi-autobiographical book Cousins, published in 1991, the cousins speak out in their colorful way, but the story has two other strands. One is the contest between two strong-willed people as they learn to accept one another within the small confines of their traveling world and despite the intrusions of the world outside it; the other, more relevant to Jiles's writing, is what we learn of her immediate family, especially her father.

Her father was an alcoholic whose recovery, when it came, was tardy. Jiles writes that "he never paid attention to me unless I made him mad," a not infrequent occurrence, since it was his habit, as a Navy veteran of World War Two, to holler "all hands on deck" whenever he wanted something done, a command that could hit a smart, strongwilled child only one way. On one occasion, after she and her older brother had disobeyed their father's orders, "we heard him hollering up there at the house. What had happened was that his rage trigger had gone off, some kind of depth charge, and once he got started he couldn't stop until it had fired off down a long chain of explosions."

Of three children, she was the one who stood up to him the most. An insurance salesman most of his life, he was charming and glib to those outside the immediate family, giving her early insights into the layers of human behavior. The family moved six or eight times when she was young, their fortunes highly variable. Her mother seems to have been a kind and loving person and, in defiance of her husband, became a talented and recognized painter later in life. Her mother's father was a brilliant 
storyteller; Paulette was his favorite. One thing all the relocations and hollering did was to leave her with no regrets about moving on.

Stormy Weather (2007) is the probably the most autobiographical novel Jiles has written, the first of three novels to be set in her adopted state of Texas. (Parts of Enemy Women (2002) are set closer to her original home in southeastern Missouri.) Young Jeanine and her two siblings live at the mercy of a charismatic and mercurial father, Jack Stoddard. They move from one Texas oilfield to the next during the hard times of the Depression. "Jack Stoddard was like a juggler tossing up jobs and dice and racehorses and ladies of the night. Sometimes he caught them all in order and sometimes he forgot where they were or that he did not have enough hands. . . Her father made up his mind to move the way birds made up their minds in midflight, wild, startling shifts that sent them spinning away through the vagrant airs to yet another oil field."

The novel is perhaps the best example of Jiles's ability to create organic authenticitya sense of aura-in a scene, combining past, present, hope, despair, and the harmonious or discordant responses of the earth itself. They had a stubby quarter horse, a winning racehorse, ugly but fast:

"Whatever her father took up it was bound to go wrong. They would move and leave Smoky Joe behind somewhere. They would lose him. He would die of sleeping sickness, he would break one of his legs. It was the same for everybody. The feeling that things were falling apart and that nothing worked. . . Even the earth itself lifted into the sky of the high plains of Texas and Oklahoma and blew into dust storms as thick as airborne petroleum."

Many of the paragraphs are like enjambed lines in her poems, breaking off, often signaling the abrupt shift from hope to sadness, or worse. Of a rare snow storm in East Texas:

"The tops of the pine trees disappeared in a foam of descending snow. It fell on the needles and lined them with spines of white and built up on the wires of the fence lot, and burdened all the sounds of the town and the derricks with a deep, submissive hush. It was a swansdown welcome for the new year, a confetti and ticker tape parade. All over the oil fields and through the overcrowded towns, each person had some small reason that the snowfall was for them alone, a sign that their lives were going to get better. 
"She watched as the flakes struck the windowpane and traced them with her fingertip down the cold glass as they slid and melted out of their ornate and classical designs. Far away the derrick lights shone into the columns of radiant drift. It was just before the bank failures of 1933, and the rest of the nation paused, dumbfounded, in their party clothes and tinfoil hats, in Chicago and New York and Los Angeles and New Orleans, while money fell like hot ashes out of the bottoms of their pockets."

\section{III.}

Wichita Falls, Texas, Winter 1870

"He had been born in 1798 and the third war of his lifetime had ended five years ago and he hoped never to see another but now the news of the world aged him more than time itself." Captain Kidd is tired, though fortunate to have a fine horse. He worries that it will be stolen. His beautiful wife, Maria Luisa, of Spanish Betancort lineage, has died. Having gone broke during the Civil War when the Confederacy forced him to buy worthless bonds, he travels to small towns, reading the news in rustic halls from mostly distant papers, listening all too intently to hear dimes drop into an empty paint can at the door. "A slow dullness had seeped into him like coal gas and he did not know what to do about it except seek out quiet and solitude. He was always impatient to get the readings over with now."

He reads a story to an uneasy crowd about the passage of the Fifteenth Amendment, which gave all Americans, regardless of race or color, the right to vote, knowing that "the general population had not settled the matter of free black people in their minds yet. All was in flux. Flux: a soldering aid that promotes the fusion of two surfaces, an unstable substance that catches fire." As he reads, he hears his audience muttering. "Stop it. I hate muttering." He has not yet thought of the curative potential of stories, or discovered the means to achieve it.

“Over all the bare heads he saw Britt Johnson and his men, Paint Crawford and Dennis Cureton, at the back wall. They were free black men. Britt was a freighter and the other two were his driving crew. They held their hats in their hands, each with one booted foot cocked up against the wall behind them." Britt has a fiftydollar gold piece. "I have a problem in my wagon," he tells the Captain, when the reading is done.

The problem is a girl, about ten years old, taken from the Kiowa, who took her from her parents after leaving them slaughtered on the prairie near Castroville. Britt has 
brought her down to Texas from Fort Sill. He does not want the gold piece he has received in payment to take the girl back to her nearest relatives, the Leonbergers, aunt and uncle. Britt knows that "if I'm caught carrying that girl it would be bad trouble. He looked the Captain straight in the eye and said, She's a white girl. You take her." Her birth name is Johanna. She thinks, "My name is Cicada. My father's name is Turning Water. My mother's name is Three Spotted. I want to go home." But the Kiowa have sold her at Fort Sill "for fifteen Hudson's Bay four-stripe blankets and a set of silver dinnerware."

The Captain buys a wagon, "painted a dark and glossy green and in gold letters on the sides it said Curative Waters East Mineral Springs Texas and he had no idea how the wagon had come all the way from near Houston to this little town on the Red River. The wagon surely had a story all to itself that would now remain forever unknown, untold." And so only after he meets Johanna does he find a wagon with curative properties and a story all to itself - it will be a vehicle and a presence in a story now set in motion. And Texas, broad, rough, and variable, demands motion at every turn.

That story features Jiles's brilliant imagining of how a half-wild girl rescued from the Kiowa, and a crusty septuagenarian with a world of wars behind him, learn to communicate - first with gestures and expressions, then in the girl's attempts at English, expressed with intonations that combine her native German and the complex Kiowa language. (Here Jiles has insights based on her own study of the Ojibway language in Canada.) The result is a generally affecting and often comedic series of exchanges. "Fery well, Cho-henna stomp foot! Cho-henna weff hont! She waved her hand. Kep-dun stend up! He stood up. Kep-dun sit don! He sat down. Kep-dun clepp honts! He wearily clapped his hands. Kep-dun laff! No, he said."

Their odyssey, of course, has many twists and turns. From the first chapter until a pivotal scene near the middle of the novel, Almay, a character who could inhabit a Cormac McCarthy novel of the West, and his two Caddo collaborators shadow Johanna (Cho-henna) and the Captain. "He had gray eyes and the thick and colorless skin of people from Scandinavia or Russia."

From the outset the Captain feels their menace; then he discovers their true interest in the blonde Johanna. The Captain and Johanna flee.

Trapped on a red sandstone bluff above the Brazos and armed only with a pistol and shotgun, they seem to have no chance against Almay and the Caddos. What happens 
next should be read or seen. Let us say that dimes paid by the Captain's audiences to hear of exotic places now become surprising messengers of the news.

Near Castroville, a German settler gives them directors to the Longberger farm. He knows he is dealing with an Amerikaner, for their conveyance has gold lettering and bullet holes. Will the Longbergers accept Johanna? Abuse her? Will she be rescued yet again? What will become of her, of the Captain?

And now there is a film. Its title is News of the World. The title of a lengthy review, featuring the film's director, Paul Greengrass, is “1870s Tom Hanks Western Brings

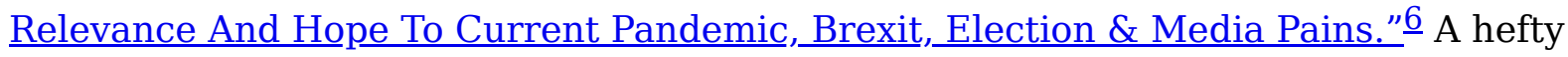
burden indeed.

Please permit a brief, final reference to Walter Benjamin. His most studied work is the essay "The Work of Art in the Age of Mechanical Reproduction." His ideas have kept art critics and scholars thrumming like a giant hive of bees since the 1930s. His ideas, and theirs, are often complex and obscure. But here's the gist of the essay, at least as it is often understood. The more remote an original story or work of art is from its origins, the more the work becomes something other than itself. It becomes owned; it becomes merchandise, or even propaganda; it becomes grist for essays and reviews. It remains a story, but the immediacy and mystery of the original story are diminished, as they have, inevitably, been diminished here.

The film is conceived and presented as a message of hope and redemption for an especially troubled time: ours. In it are racists, lying journalists, political zealots, and predators, none of whom prevail. It is clear that the Captain/Kep-dun and Johanna/Chohenna need and find each other as they journey toward mutual redemption. They bridge gaps of age, culture, language, and gender. The Captain sees people as they are.

The film does not stray too far from the story when it emphasizes the ameliorative impact of the Captain's readings, once they are "dressed" to communicate not only information but the mysterious power of the real news-the curative story. But filmmakers, like historians, rarely avoid the temptations of presentism. While hope and redemption are transcendent qualities, revealed in many wonderful stories, the title of 
the film review foregrounds the ills of our moment, as if to justify the story as a filmic remedy for our times. The review is all too predictive.

In the novel, the Captain regards Britt Johnson, a Black man, as his equal. Britt Johnson existed; he spent months in 1865 trying to rescue his wife, whom the Comanche had captured. 7 In the film, this Black man does not appear. In his place, we see a dead Black man, left lynched on the prairie with a note pinned across his chest: "Texas Says No! This is White Man's Country." We do not see or hear this man before the Captain discovers him. His hanging body speaks of the horror and cruelty of the time but does not speak for, or about, him as a person. Later in the scene, the Captain chases down a terrified Johanna, who was traveling to Castroville under the man's protection after being taken from her Kiowa captors.

Even though the scene reminds us of the continuing brutality against Black people in the present day, it deprives us of the man, and character, of Britt Johnson, as well as the excellent opening scenes in the novel that describe how the Captain encountered Johanna through Britt's intervention. The scene described earlier in this essay conveys the risks that freedmen such as Britt had to navigate, if they could, during Reconstruction. He and the Captain realize that Britt might be killed if he is caught transporting a White girl. The decision to transfer Johanna from Britt's freight wagon to the Captain hinges on this shared knowledge between two good men, one Black, one White, at a time when hostility between the races was intense. The common humanity they find anticipates the enduring bonds that develop between the Captain and Johanna, initially separated by culture rather than race. Johanna and the Captain are the film; it depends on the bridges they build. There is no bridge to Britt Johnson.

The film turns the Captain into a veteran of the Civil War; and in the film it is the war, not his essential nature, which has made him into a solitary, wandering soul. All of the reviews emphasize his status as a veteran of that war. In the novel, however, he is a printer in San Antonio during the war; the worthless securities the Confederate government compels him to buy has left the elderly Captain bankrupt. In making the Captain a Confederate veteran, the director has enabled many reviewers to describe the film as "True Grit Meets The Searchers,"- or as "a cross between True Grit and The Searchers," since John Wayne's character in the latter movie had also fought for the Confederacy and his roles in both films featured him as a hard-bitten protector of young women. $\underline{8}$ One can imagine an elevator pitch for the film using the same words the reviewers have chosen. 
Of greater importance is that the Captain's life becomes confined to the Civil War and its aftermath. Gone is the messenger in General Jackson's army and the Captain who earned his bars in the Mexican War. The long arc of the novel - more than half a century - shrinks to a span of a decade or so, a decade whose impact on our present is obvious but, sadly, makes the Captain less a true messenger than a man forced by chance to become a compassionate wagoneer. Inevitably, the reproduction of Jiles's novel has become a vehicle for its own messages. Those messages do not ruin the movie; some will find in it the relevance and hope the director envisioned.

The last words here, though, will come from the Captain of the novel, the natural runner: "Maybe life is just carrying news. Surviving to carry the news. Maybe we have just one message, and it is delivered to us when we are born and we are never sure what it says; it may have nothing to do with us personally but it must be carried by hand through a life, all the way, and at the end handed over, sealed."

John Willingham is an op-ed contributor to the History News Network and an essayist and short story writer with work published in Southwest Review. He is completing a novel based on the travels of Frenchy McCormick, who ran away from Baton Rouge as a girl after the Civil War and became a legend in the Texas Panhandle.

\section{Footnotes}

1. Edmund Jephcott, M. P. B. H. E. G. S. M. W. J., et al. Selected Writings: 1938-1940. Belknap Press, 1996, p. 253, https://books.google.com/books?id=tD1AupO0vvoC.. 2. Paulette Jiles, "The Spontaneously Created People, "Southwest Review, Vol. 78, No. 2 (Spring 1993), pp. 267-275

3. Francis Mansbridge, "The Voyage That Never Ends: The Poetry of Paulette Jiles," Essays on Canadian Writing, Spring 91, Issue 43, pp. 153-164

4. M. Travis Lane, in Heart on Fist, Essays and Reviews 1970-2016, "Traveling with St. Theresa: The Poetry of Paulette Jiles, "Windsor, Ontario, Palimpsest Press, pp. $118-131 \leftrightharpoons$ 
5. Elizabeth Mills, "A Manual of Etiquette: An Interview with Paulette Jiles," Southwest Review, Vol. 78, No. 2, (Spring 1993), pp. 245-266 ヒ

6.

Jr, Mike Fleming, and Mike Fleming Jr. “Paul Greengrass' 'News Of The World': 1870s Tom Hanks Western Brings Relevance And Hope To Current Pandemic, Brexit, Election \& Media Pains - Deadline Q\&A.” Deadline, 1 Dec. 2020, https://deadline.com/2020/12/paul-greengrass-news-of-the-world-tom-hanksuniversal-pictures-1870-western-interview-1234635664/.

$\underline{\underline{ }}$

7.

Texas State Historical Association / Johnson, Britton.

https://www.tshaonline.org/handbook/entries/johnson-

britton\#: : :text=Britton\%20(Britt)\%20Johnson\%20was\%20born,Creek\%20Raid\%20of \%200ctober\%201864. Accessed 2 Feb. 2021.

$\stackrel{\oplus}{2}$

8.

Debruge, Peter, and Peter Debruge. "'News of the World' Review: 'True Grit' Meets 'The Searchers' in Dry Tom Hanks Western." Variety, 11 Dec. 2020, https://variety.com/2020/film/reviews/news-of-the-world-review-tom-hanks$\underline{1234850145 / .}$

$\underline{-}$ 